\title{
Non-formal Astronomy Education in Brazil: Analysis of works published in national scientific events
}

\author{
Leandro Donizete Moraes \\ Universidade Cruzeiro do Sul, Brazil \\ leandrosta2009@hotmail.com \\ Ismar Frango Silveira \\ Universidade Cruzeiro do Sul, Brazil
}

\begin{abstract}
This article aims to reflect on research trends on non-formal education in astronomy through the analysis of national scientific events. In this state-of-the-art research, we use content analysis by Laurence Bardin and identify 328 papers presented in oral and panel communications. We analyzed this sample through five categories of analysis: Scientific Event; Year of publication; Region; Institution and Thematic Focus. Among the trends, research was presented in non-formal spaces, the use of technology and the approximation between formal and non-formal education through activities such as sky observations. As for the challenges, we identified few studies from the North, Northeast and Midwest. In addition, the history of indigenous, cultural and amateur astronomy, inclusion and astronomy is lacking research, showing that the area is still diffuse and needs closer ties between its various actors.
\end{abstract}

Keywords. Astronomy education, State of art, Non-formal education

\section{Introduction}

The relentless pursuit of understanding celestial phenomena and the origin, evolution and destiny of the universe make astronomy one of the most captivating and emblematic sciences. Curiosity and motivation for astronomical studies have led to various scientific theories and technological advances, placing astronomy among the most important sciences for human development. Even with this importance, we observe several problems in the teaching of astronomy inside and outside our schools. Langhi (2011), for example, analyzed several alternative conceptions about astronomical phenomena; Bretones and Compiani (2010) identified problems in teacher education and Yano (2017) noted the misuse of nonformal spaces of education.

Many researchers seek solutions to the problems faced in astronomy education. Among them, Borges (2017) elaborated a didactic sequence after visiting a mobile planetarium; Rosa (2015) analyzed the possibilities of approximation between the school and observatories; Spina (2017) proposed alternatives for the teaching of astronomy through the use of blogs; Arizono (2016) evaluated the use of animations in astronomy; Beliz (2016) created an astronomical virtual game and Ortiz (2014) reflected on the importance of indigenous astronomy. In addition to researchers, many teachers, amateur astronomers, and enthusiasts work so that people can learn astronomy in schools and elsewhere through formal, non-formal, and informal education. 
We can teach astronomy in official schools through formal education which, according to Langhi and Nardi (2009), is the type of education offered in school environments, where knowledge is organized, systematized and structured. For Marranghello et al (2018), formal education requires well-defined behavioral standards, rules and content. Regarding non-formal education, Resende (2017) explains that it is a more diffuse type of education, with flexible times. Marques (2017) analyzes that non-formal education is systematized and organized, but has greater flexibility in terms of time and learning spaces. Observatories, planetariums and science centers are examples of places where it can occur. Informal education is one that occurs during life, through reading newspapers, in the workplace or in conversations with friends. For Gohn (2006), this type of education occurs through socialization, through behaviors, worldviews, language use, beliefs, among other characteristics.

In this research we analyze the non-formal education in Astronomy in Brazil, through the works presented in the last five editions of the main national scientific events related to Astronomy education. The choice for the analysis of scientific events is due to the fact that much of the research presented in these events is not published in journals or in theses and dissertations. Therefore, when analyzing the productions of scientific events, we have the opportunity to identify various aspects of the studied area that would not be possible with the analysis of journals or theses and dissertations.

To identify this production and analyze trends and results, we conducted a state of the art research. According to André (2001), this type of research critically reviews and analyzes the production of a certain area in search of improvements. For the organization, exploration of material and treatment of results, we use Bardin's (2006) content analysis. We also analyzed the contributions of other authors who conducted this type of research. Among them, Bueno et al (2019) analyzed research in Astronomy education related to knowledge about the sky of indigenous cultures; Bussi and Bretones (2013) mapped the production in Astronomy education in the works of the National Science Education Research Meetings - ENPEC; Buffon et al (2019) analyzed teacher education in database theses and dissertations and Santos et al (2019) investigated the use of technology in astronomy teaching.

\section{Methodology}

This state-of-the-art research, with a qualitative approach, aims to analyze the trends and results of academic production at national scientific events on non-formal education in astronomy. According to Ferreira (2002), this type of research has a bibliographic character, mapping and discussing a certain academic production, seeking answers on which aspects and dimensions are being highlighted in different times and places. Megid Neto (2009) explains that the state of the art seeks to know characteristics and trends of a certain field of knowledge through the academic production linked to it. We use the content analysis of Bardin (2006), through its three phases: a) pre-analysis; b) exploration of the material and c) treatment of the results: inference and interpretation. The pre-analysis consists of an organization phase. In this first phase, there are four processes, the first being floating reading, in which we need to establish the data collection documents. Then we choose the documents, formulate the hypotheses and objectives and, finally, we elaborate the indicators.

We adhere to the document selection criteria proposed by Bardin (2006). According to Silva et al (2017), these criteria are completeness, in which we must be careful to exhaust the entire communication, because we cannot omit anything; the representativeness, in which there must be information about the universe to be researched in the documents under analysis; homogeneity, as the data must refer to the theme being analyzed and pertinence, 
because the documents must be consistent with the objectives pursued in the research. In the second phase, the material is explored to identify and construct analysis categories. Bardin (2006) explains that it is necessary an exclusivity criterion, so that the constituent elements are categorized in only one parameter. The last phase consists of the treatment of results, inference and interpretation. At this stage it is necessary to use intuition and critical and reflexive analysis.

Initially, we made a bibliographic survey about the works presented in oral communications and panels present in the last five editions of the main national scientific events related to education in astronomy. Then, in the light of Bardin (2006), we started the pre-analysis by fluctuating reading the works obtained through the bibliographic survey. Then we selected the works on education in astronomy.

We identified, among the selected works, those that specifically refer to non-formal education in astronomy. After identifying the works, we draw as an initial hypothesis that non-formal education in astronomy allows access to astronomical knowledge to people not necessarily linked to educational institutions. In many situations, these people learn the true causes of astronomical phenomena, thereby diminishing alternative conceptions that existed prior to exposure to activities pertinent to this type of education.

To carry out the second phase of analysis, exploration of the material, we established the following categories of analysis: Scientific event; Year of publication; Region; Institution and Thematic Focus. In the categories Scientific Event and Year of publication, all works on astronomy education in general and non-formal astronomy education were analyzed. For the other categories of analysis we use only works related to non-formal education in astronomy. This separation was necessary due to the fact that our objective in this research is to analyze the production in non-formal education in astronomy. Thus, the first two categories situated our work in the field of astronomy education, and then we analyzed only the works on nonformal education in astronomy. In the last phase, we continue the analysis and interpretation of the results, through the construction of graphs and tables from the data referring to the analysis categories.

\section{Results and discussions}

Analysis of scientific events

We analyze the last five editions of the main Brazilian scientific events related to astronomy education. Thus, we identified the last five Bulletins of the Annual Meetings of the Brazilian Astronomical Society - SAB Meetings; the last five minutes of the National Symposium on Astronomy Education - SNEA; the National Symposium on Physics Teaching - SNEF and the Research Meeting on Physics Teaching - EPEF and the last five Annals of the National Meeting on Research in Science Education - ENPEC. Table 1 presents the work of these events. Table 1 presents the relationship between the scientific events and the works:

Table 1. Number of works on astronomy education in general and non-formal astronomy education presented in the analyzed events.

\begin{tabular}{llclr}
\hline \multirow{2}{*}{ Event } & Edition & $\begin{array}{l}\text { Astronomy education } \\
\text { in general }\end{array}$ & $\begin{array}{l}\text { Non } \\
\text { Education } \\
\text { Astronomy }\end{array}$ & $\begin{array}{r}\text { Formal } \\
\text { in }\end{array}$ \\
\hline SAB Meetings & XXXIX Meeting (2015) & 29 & 19 \\
& XL Meeting (2016) & 26 & 13 \\
& XLI Meeting (2017) & 29 & 08 \\
\hline
\end{tabular}




\section{(10) TECHNIUM}

Technium Social Sciences Journal

Vol. 3, 37-50, February 2020

ISSN: 2668-7798

www.techniumscience.com

\begin{tabular}{|c|c|c|c|}
\hline & XLII Meeting (2018) & 23 & 06 \\
\hline & XLIII Meeting (2019) & 30 & 17 \\
\hline \multirow[t]{5}{*}{ SNEA } & I SNEA (2011) & 98 & 38 \\
\hline & II SNEA (2012) & 86 & 23 \\
\hline & III SNEA (2014) & 123 & 33 \\
\hline & IV SNEA (2016) & 96 & 25 \\
\hline & V SNEA (2018) & 128 & 28 \\
\hline \multirow[t]{5}{*}{ SNEF } & XIX SNEF (2011) & 31 & 12 \\
\hline & XX SNEF (2013) & 39 & 12 \\
\hline & XXI SNEF (2015) & 41 & 16 \\
\hline & XXII SNEF (2017) & 53 & 14 \\
\hline & XXIII SNEF (2019) & 35 & 17 \\
\hline \multirow[t]{5}{*}{ EPEF } & XIII EPEF (2011) & 16 & 07 \\
\hline & XIV EPEF (2012) & 06 & 01 \\
\hline & XV EPEF (2014) & 05 & 01 \\
\hline & XVI EPEF (2016) & 15 & 07 \\
\hline & XVII EPEF (2018) & 06 & 02 \\
\hline \multirow[t]{5}{*}{ ENPEC } & VIII ENPEC (2011) & 14 & 04 \\
\hline & IX ENPEC (2013) & 19 & 05 \\
\hline & X ENPEC (2015) & 18 & 06 \\
\hline & XI ENPEC (2017) & 19 & 06 \\
\hline & XII ENPEC (2019) & 23 & 08 \\
\hline Total & & 1008 & 328 \\
\hline
\end{tabular}

Following, we made the pre-analysis, from the identification of the works presented in oral communications and panels on Astronomy education. Among these works, we identified those who have specific research on non-formal education in astronomy. In this preanalysis, we seek to identify the theme of the work by reading the titles, abstracts and keywords. In some cases full work analysis was required when available.

Analyzing Table 1, we observed that 1008 works on astronomy education were identified, in general. Of these works, 328 (32.5\% of the total) present research on non-formal education in astronomy. In the other 680 works, we identified research on the presence of astronomy in formal environments; initial and continuing teacher training in astronomy; analysis of alternative conceptions in school environments and textbooks; teaching practice in astronomy; curricular proposals for astronomy education; didactic sequences; use of technology in the formal teaching of astronomy; assessment of astronomy learning in schools; discussions about the teaching of Astronomy related to the Science, Technology and Society movement - CTS; the use of literature in astronomy in the classroom; interdisciplinary between astronomy and other sciences; didactic resources of astronomy; inclusion activities in astronomy; analysis of academic production in astronomy education; scientific literacy in astronomy; Astronomy present in official documents, among other researches.

The Annual Meeting of the Brazilian Astronomical Society - SAB Meetings, allows the dissemination and discussion of works related to all areas of astronomy research in Brazil. Presents conferences and lectures with experts from Brazil and abroad, oral communication sessions and panel presentations, among other activities. In our analysis, presented in Table 1, we identified that the production on Astronomy education present in these meetings, remained 
between 23 and 30 annual works and that there was a decrease in works on non-formal education in Astronomy between 2016 and 2018.

The National Symposium on Astronomy Education - SNEA, is a specific national forum for discussion and presentation of works on astronomy education. It is a recent event, but already has a significant amount of work. In Table 1, we can see that the number of papers presented on astronomy education in general remained between 86 and 128 papers and the works on non-formal education in astronomy ranged from 23 to 38 .

The National Symposium of Physics Teaching - SNEF, is already a traditional event in Brazil, starting its activities in 1970. This symposium discusses the challenges of physics teaching through themes relevant to the academic community of the area. In our research, we identified between 31 and 53 annual works on astronomy education in general. Regarding the works in non-formal education, we observed in Table 1, between 12 and 17 annual works.

The Physics Teaching Research Meeting - EPEF, discusses the advances and progress in physics teaching through the dissemination and discussion of the academic production of the area. As can be seen from Table 1, the EPEF presents a small amount of work on astronomy education, in general, ranging from 5 to 16 annual works. On non-formal education in astronomy, it is the analyzed event that has the smallest number of works, ranging from 01 to 07 works.

The National Meeting of Research in Science Education - ENPEC, brings together researchers of education in physics, biology, chemistry and related areas. Its activities include roundtables, conferences, conversation wheels, panel presentations, meetings and other activities. In Table 1, we observe that this event presents a small amount of works on astronomy education and ranging from 14 to 23 works and non-formal astronomy education between 04 and 08 works.

The largest proportion of non-formal astronomy education work in relation to the total analyzed was presented at the XXXIX SAB Annual Meeting in 2015, in which $65.5 \%$ of works on astronomy education referred to non-formal education. The lowest proportion was identified at the XIV EPEF in 2012, with only $16.7 \%$ of works on non-formal education in astronomy. These data show the importance of non-formal astronomy education and its contributions to astronomy education.

Year of publication

Looking at Table 1, we realize that some scientific events are held in different years and that, before 2015, we did not analyze the SAB Meetings. Therefore, in Figure 1 we analyze the works published between 2015 and 2019.

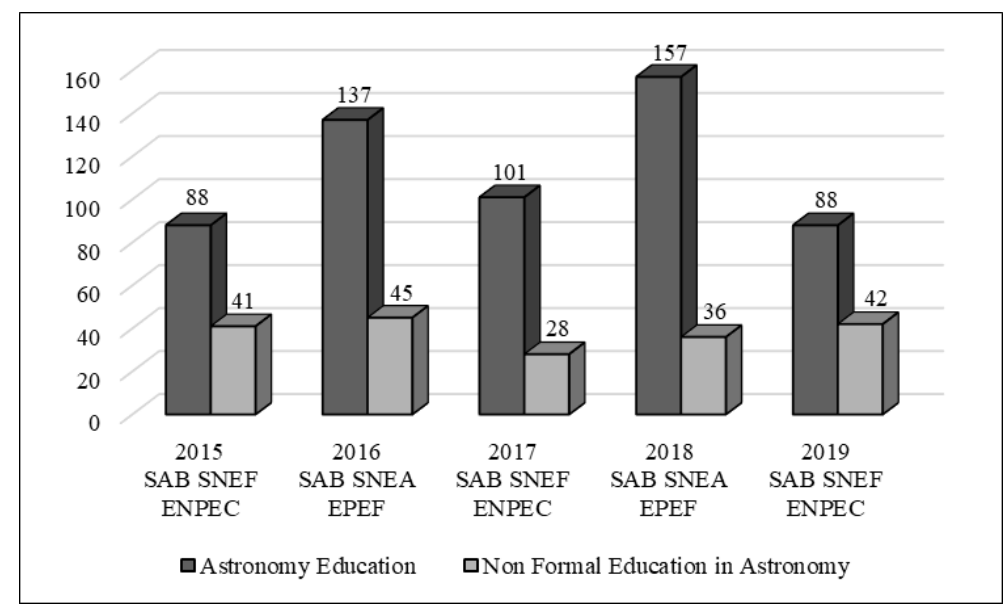


Figure 1 - Number of works on astronomy education present between 2015 and 2019

Looking at Figure 1, we noticed that the SAB, SNEF and ENPEC meetings took place in 2015, 2017 and 2019. The amount of work on astronomy education in these years increased in 2017 and returned to the same initial amount in 2019. About the work of nonformal education in astronomy, there was a decrease in 2017 and an increase in 2019. SAB meetings were held jointly with SNEA and EPEF in 2016 and 2018. In these years there has been an increase in the number of works on astronomy education and a decrease in the amount of work on non-formal education in astronomy. In general, when analyzing the five years, we realize that the presence of SNEA in 2016 and 2018 contributed to the increase in the production of astronomy education in these years. Production in 2015 and 2019 remained practically constant, in 2018 there was the lowest proportion between non-formal education in astronomy and total work (22.9\%) and in 2019 the highest proportion (47.7\%).

Table 1 and Figure 1 show that the annual output in astronomy education in general and non-formal astronomy education depends on the events held in the respective year. However, there were no significant increases in this production in the analysis of events separately or together in the five years. In recent decades there have been advances in astronomy education in Brazil, through the creation of SNEA and diversified productions in scientific events, journals and theses and dissertations, for example. However, in this analysis and in the literature of the area we observe that much remains to be done, because, according to Langhi (2011), national actions for astronomy education are necessary.

After analyzing the events and year of publication of all works, we made a specific analysis of the works on non-formal education in astronomy. In light of Bardin (2006), we established the other categories of analysis: Region; Institution and Thematic Focus.

\section{Geographic Region}

Papers on non-formal education in astronomy were presented at five national events in science, physics and astronomy education. Thus, authors from different regions of Brazil and other countries participated in these events. Figure 2 presents the list of works and their respective regions:

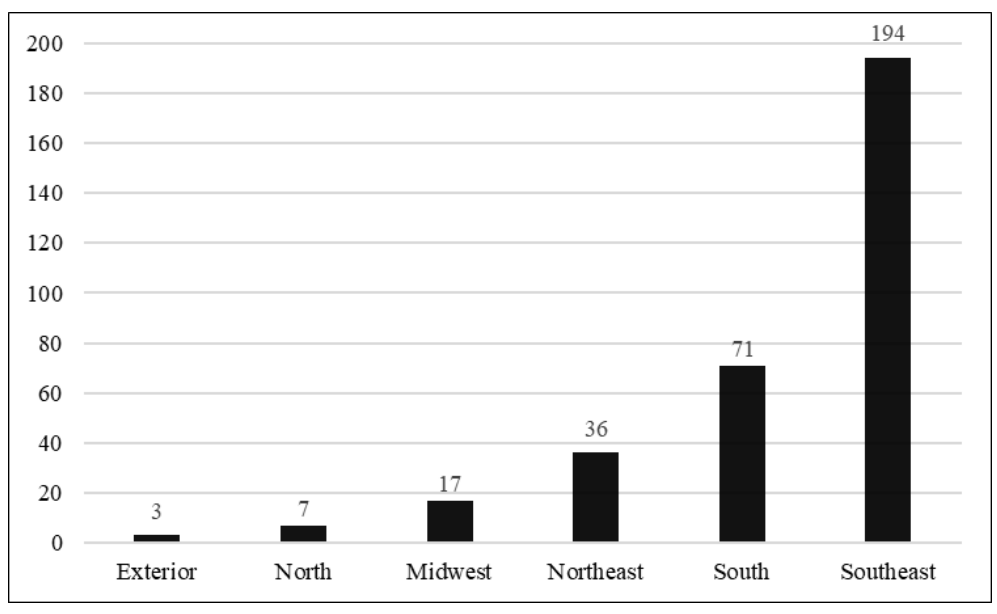

Figure 2 - Geographic region of works on non-formal education in Astronomy. 
It can be observed in Figure 2 that the Southeast region presented the largest amount of works, with a total of $194(59.1 \%)$ and the South region presented 71 works $(21.6 \%)$. The other regions presented smaller quantities of works, such as the Northeast with 36 works $(11 \%)$, the Midwest with 17 works (5.2\%), the North region with 7 works $(2.1 \%)$ and 3 works $(0,9 \%)$ were presented by authors from other countries, two from Argentina and one from Spain.

We note that actions are needed to encourage this production in all regions of Brazil. According to Figure 2, this distribution is heterogeneous. The same happens with the distribution of non-formal spaces, such as planetariums, observatories, museums and science centers.

Marques (2017) analyzed that this distribution is unbalanced and there is a great lack of non-formal institutions and spaces. Falcão (2009) analyzes that there must be a greater amount of these non-formal spaces and be better distributed in Brazil. These spaces are usually in prime regions and in the center of the capitals, allowing only a small portion of the population to access them. For the author, these spaces contribute to social inclusion through scientific knowledge and the dissemination and popularization of astronomy.

Even with the problems related to this heterogeneous distribution, several actions have already been taken in Brazil to teach astronomy in its different regions. Among the examples, at the International Year of Astronomy, in 2009, activities were performed in all regions of Brazil; the Brazilian Astronomy and Astronautics Olympiad - OBA, is available to schools in all regions; There have been editions of the events analyzed in the North, Northeast and Midwest regions and the use of technology, especially the Internet, has taken the teaching of astronomy to various regions of the country. To analyze in more detail the specific aspects of production in each region, we also analyze the institutions of origin.

Institutions of origin of the works

We identified the total of 94 source institutions of the analyzed works. As this amount is high, we create a word cloud through the WordArt tool (https://www.wordart.com). In Figure 3 we observe that the larger the words, the greater the number of papers presented by each institution. 


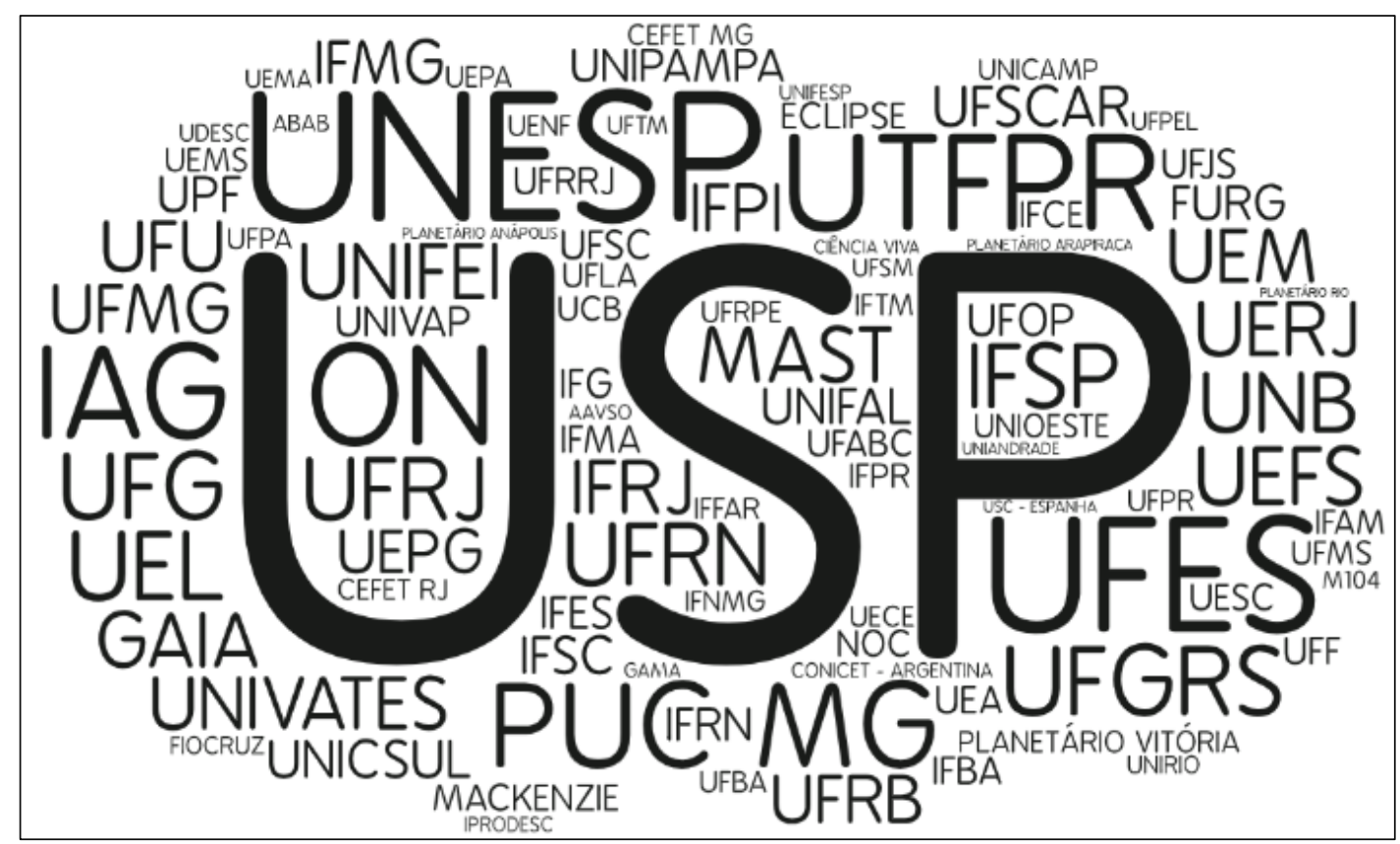

Figure 3 - Home institution of works on non-formal education in astronomy.

The word cloud shown in Figure 3 shows that the University of São Paulo - USP, was the institution with the largest number of works, totaling 41 works; Paulist State University Julio de Mesquita Filho - UNESP, participated with 25 works; the Federal Technological University of Paraná - UTFPR, presented 18 papers; the Pontifical Catholic University of Minas Gerais - PUC MG, had 16 works; the Federal University of Espírito Santo - UFES, presented 13 papers; the Federal University of Rio Grande do Sul - UFRGS, participated in the events with 12 works; the University of Taquari Valley - UNIVATES, had 11 papers and the University of Rio Grande do Norte - UFRN, presented 10 papers. The other institutions presented less than ten papers. Following, we separate the types of institutions and the amount of work of each institution is presented in parentheses.

Of the 94 institutions, 31 are federal universities: UTFPR (18), UFES (13), UFRGS (12), UFRN (10), UFSCAR (8), UNIFEI (6), UFRJ (6), UFMG (6), UFG (6), UFRB (4), UNB (4), UNIPAMPA (4), UFU (4), UNIFAL (3), FURG (3), UFOP (2), UFABC (2), UFSC (2), UFRRJ (2), UFJS (2), UFMS (2), UFRPE (1), UFLA (1), UFPR (1), UFPA (1), UFF (1), UNIFESP (1), UFBA (1), UFPEL (1), UFSM (1) and UFTM (1). There are 16 federal institutes: IFSP (5), IFRJ (4), IFMG (3), IFSC (3), IFPI (3), IFRN (2), IFMA (2), IFES (2), IFNMG (1), IFPR (1), IFFAR (1), IFBA (1), IFAM (1), IFCE (1), IFTM (1) and IFG (1). Two institutions are Federal Centers for Technological Education: CEFET MG (2) and CEFET RJ (2). Eighteen are state universities: USP (41), UNESP (25), UEFS (6), UEL (5), EMU (5), UERJ (4), UEPG (4), UNIOESTE (2), UNICAMP (2), UESC (2), UEMS (1), UEMA (1), UNIRIO (1), UEPA (1), UEA (1), UDESC (1), UECE (1) and UENF (1). Eight are private universities: PUC MG (16), UNIVATES (11), UNICSUL (5), MACKENZIE (3), UNIVAP (3), UPF (2), UCB (1) and UNIANDRADE (1).

Four planetariums presented works: Vitória Planetarium (5), Arapiraca Planetarium and Science House (2), Anapolis Planetarium (2) and Rio de Janeiro Planetarium (1). The astronomy groups that participated in the research were: GAIA Group (5), GAMA Group (1) and M-104 Group (1). The Eclipse Astronomy Club and the Sky Observation Nucleus - NOC, 
presented one paper each. The Museum of Astronomy and Related Sciences - MAST, participated with nine works and the National Observatory - ON, participated with six works. The Institute of Astronomy, Geophysics and Atmospheric Sciences - IAG, participated with nine works. The Complejo Plaza Del Cielo - CONICET, from Argentina, presented two works. The other institutions presented only one work: Living Science Museum; Oswaldo Cruz Foundation - FIOCRUZ, IPRODESC Institute, American Association of Variable Star Observers - AAVSO, Brazilian Association of Biodynamic Agriculture - ABAB, and the University of Santiago de Compostela - USC, Spain.

Looking at the institutions, we identified the presence of $31(33 \%)$ federal universities, $16(17 \%)$ federal institutes, 2 (2.1\%) federal technology education centers, 18 (19.1\%) state universities and $8(8.6 \%)$ private universities. The other $19(20.2 \%)$ institutions are planetariums, science clubs, astronomy groups, astronomy centers, research institutions, institutes, associations, observatories, museums and foreign institutions.

These data reveal unique characteristics of the non-formal area of astronomy education, since several institutions that presented works are not formal educational institutions, such as planetariums and science clubs, for example. We can also observe that the northern region had only public educational institutions (IFAM, IFMA, UEMA, UEPA, UEA and UFPA), this fact shows the importance of investing in public education for people from different places in Brazil to have access to education. The eight private institutions demonstrate the importance of research in the private sector, as they presented $48(12.8 \%)$ papers. Although the institutions analyzed are concentrated only in south-central Brazil, they also play an important role in the production of works on non-formal education in astronomy.

In general, we can assess the importance of institutions for their respective regions through non-formal education in astronomy. Many universities maintain observatories, planetariums and outreach activities. Some activities are held on campus and others on school visits or traveling shows. In addition to formal educational institutions, astronomy clubs, centers and centers are of interest to the public, encouraging people to study content that is not usually learned in schools. The institutes, associations, museums, planetariums and other institutions promote astronomy through diversified activities such as sky observations and research, for example. The analysis of these different institutions demonstrates the importance of the union between professionals and amateurs for people to learn about astronomy. Marques (2017) analyzed the complexity of the area of non-formal education and scientific dissemination in astronomy in Brazil, noting that many actions are isolated, with wide variation at national level. The areas own meetings are sectarian, with SAB members, educators, planetarists, and amateur astronomers at distinct events without effective approaches. There is a lack of communication and exchange of experiences, so actions are needed for the various actors of non-formal astronomy education to work in concert for the area to develop and to allow the participation of all regions.

Thematic focus and sub focus

After analysing the events, year of publication, region and institution of origin of the work, we study the thematic focuses. We identified six thematic focuses that are presented in Table 2.

Table 2. Thematic focuses and sub focus of the analyzed works.

Thematic focus Thematic Sub focus Quantity of works




\begin{tabular}{lll}
\hline Theoretical approach & Experiment Demo & 04 \\
& Survey Surveys & 11 \\
Astronomy & Construction and use of teaching materials & 23 \\
Education & Educator Training & 20 \\
Formal Spaces & Surveys with participants & 32 \\
& Use of formal space for non-formal & 39 \\
& activities & 09 \\
& Knowledge Olympics & \\
Non-formal spaces & Amateur Astronomy & 01 \\
& Itinerary Activities & 22 \\
& Inclusion & 11 \\
& Reporting of activities in non-formal spaces & 101 \\
& & \\
Culture and history & Cultural Astronomy & 09 \\
& Indigenous Astronomy & 06 \\
& Activities on the history of Astronomy & 09 \\
& & 15 \\
Technology & Technological resource building & 16 \\
\hline
\end{tabular}

The thematic focus "Theoretical Approach" presents theoretical works related to non-formal education in astronomy. The works belonging to the first sub focus "Demonstration of experiments", explain the calculation of the terrestrial rotation velocity; the dynamics of the seasons; calculations on solar activity and ecliptic obliquity. In the "Survey Surveys" sub focus, the authors presented survey results on the use of comic strips in non-formal astronomy education; survey of works on Cosmology; astronomy websites; surveys of sky observations; number of Brazilian observatories and planetariums; analysis of textbooks; works on non-formal education in astronomy and digital games.

The focus on "Astronomy Education" presents research on teacher and instructor training; research with participants of non-formal activities in planetariums, science centers, observatories and other spaces and materials for non-formal teaching of astronomy. In the sub focus "Construction and use of teaching materials", the authors reported the steps for the construction and use of mini planetariums; telescopes; spotting scope; summit sessions; Sun Watch; Moon phase model; models; homemade astrolabe; printed telescope; spectroscopy activities; folding; agricultural astronomical calendar; board games; Card games and homemade heavenly projector. The works presented in the sub focus "Educator Training", analyzed the teacher formation through activities in planetariums; visits to observatories; courses and workshops and other activities pertaining to non-formal education. Reflections were also made on the formation of monitors to work in non-formal spaces, such as planetariums and observatories. In the last sub focus "Surveys with participants", research was conducted on the acceptability of activities carried out in non-formal spaces; alternative conceptions of students, teachers and the general public of non-formal spaces.

The "Formal Spaces" focus has works related to non-formal activities done in schools and other formal educational institutions and the knowledge Olympics. In the sub focus "Using formal space for non-formal activities", reports on the construction of astronomy clubs and centers in schools are presented; interdisciplinary workshops; projects 
with songs and comics; readings; rocket workshops; jokes; activities related to the preservation of the environment and the Eratosthenes Brasil Project. The "Knowledge Olympics" focus presents the results of astronomy-related Olympics; activities proposed by these Olympics; preparations for the Olympics through courses and workshops and analysis of Olympic issues.

The works in the focus "Non-formal spaces" analyzed activities and concepts related to the teaching of astronomy through itinerant activities, amateur astronomy and the use of inclusive activities in non-formal spaces. Only one paper presented activities in the "Amateur Astronomy" sub focus, showing that more research is needed on the contributions of amateur astronomers to the teaching of astronomy. The sub focus "Traveling Activities" presents reports of this type of activity; mobile planetariums and traveling shows. The works of the "Inclusion" sub focus report the use of activities adapted to non-formal spaces for the visually impaired, the elderly and students with high skills; activities with inclusive materials and reflections on the importance of inclusion in non-formal education in astronomy. In the sub focus "Report on activities in non-formal spaces" are presented descriptions of activities performed by observatories, planetariums, science centers and other spaces. In these descriptions the authors present the activities performed in these spaces and the results.

The focus "Culture and history" exhibits works aimed at valuing the culture and history of astronomy and works on indigenous astronomy. The first sub focus "Cultural Astronomy" reports the use of tales, myths, artifacts and arts of ancient peoples that relate to astronomy. The sub focus "Indigenous Astronomy" describes activities on indigenous tribes; explanations about indigenous constellations and valorization of indigenous astronomy through planetary sessions that address this theme. The focus "Activities on the history of astronomy" presents activities with music, movies, literary works, theaters, lectures and short stories that bring to the public aspects of the history of astronomy and the importance of preserving it. The last thematic focus "Technology" presents works that used or built technological resources in non-formal education in astronomy. The sub focus "Building technological resources" introduces the creation of online courses; interactive materials; applications; radio programs; blogs; online questionnaires and video production. The sub focus "Use of technological resources" presents works on the use of Internet pages; use of software such as Arduino, Celestia and Stellarium; online games; virtual observatories and social networks such as Facebook, Twitter and Youtube.

By analyzing the thematic foci and sub focus we observe that non-formal education in astronomy is present in many spaces and many different actors participate in its activities. 15 papers (4.6\%) have a "Theoretical Approach"; 75 papers $(22.7 \%)$ presented the "Astronomy Education"; "Formal Spaces" were identified in 48 works (14.6\%); the "nonformal spaces" were analyzed in 135 works $(41.2 \%)$; 24 papers $(7.3 \%)$ presented research on "Culture and history", valuing important aspects of cultural astronomy, indigenous astronomy and the history of astronomy and 31 papers $(9.5 \%)$ presented research using "Technology", showing the importance of technology in non-formal education.

\section{Conclusion}

In this research we identified several aspects of non-formal education in astronomy through the analyzed works. The choice to analyze scientific events was due to the fact that much research presented in these events is not published in journals, theses or dissertations. In addition, these surveys are conducted in formal educational institutions; Astronomy clubs, centers and centers; museums; planetary; observatories; associations and other institutions. This diversity of institutions reinforces the complexity of non-formal astronomy education in 
Brazil, showing that its actors must work together in search of efficient results in all regions of the country. Regarding the regions, we observed that the North, Northeast and Midwest were the regions with the least amount of work. We also observed that the analysis of the last five years did not show significant increases in the area's production, showing that several researches need to be performed, as this area is still little explored in Brazil.

In the 252 papers presented in panels and in the 76 oral communications, contents on observational astronomy in general were presented; eclipses; constellations; moon phases; planets; heavenly sphere; solar system; calendars; myths; cosmology; astrobiology; astrophotography; astrophysics; Indigenous astronomy; Cultural astronomy; Amateur astronomy; astronomical instruments; ethno astronomy; gravitational waves; radio astronomy; satellites, among others. This diversity of content demonstrates the importance of non-formal education for astronomy learning.

The data we analyzed point to trends in non-formal education, such as research and the use of non-formal spaces; the use of technology and the growing approximation between formal and non-formal education. This approach occurs through non-formal activities carried out in educational establishments, such as astronomical observations, courses, workshops, knowledge Olympics and projects such as the Eratosthenes Brazil Project. About this project, Santos et al (2012) explain that he proposes the measurement of the earth radius starting from the principles that Eratosthenes used. The project is an international action that encourages students and the general public to learn astronomy.

Among the challenges, we note that cultural, indigenous and amateur astronomy do not yet have the necessary space. Similarly, the history of astronomy and inclusion also lack research. Although 31 papers on technology were presented, many other technological resources can be used, such as the Internet, for example, and online courses, such as Massive Open Online Courses - MOOCs that were present in just one paper. Regarding the geographic regions, the North, Northeast and Midwest regions need more research focused on non-formal astronomy education through research in public and private universities and non-formal education spaces, among other actions. The data obtained in this research represent a valuable sample for non-formal education in astronomy. These data show the interest of many people, both professionals and amateurs, seeking solutions to the various problems faced by this area. There are several possibilities for non-formal education in astronomy, but as Langhi (2011) has already warned us, national actions are necessary for this area to develop efficiently and to contribute to education in Brazil.

\section{References}

[1] ANDRÉ, M. E. D. A. Pesquisa em educação: buscando rigor e qualidade. Cadernos de Pesquisa, São Paulo, n. 113, p. 51-64, 2001.

[2] ARIZONO, E. C. Animação como ferramenta no ensino não formal em Astronomia. 2016. 158f. Dissertação (Mestrado Profissional em Ensino de Astronomia) - Instituto de Astronomia, Geofísica e Ciências Atmosféricas, Universidade de São Paulo, São Paulo, 2016. [3] BARDIN, L. Análise de conteúdo. Lisboa: Edições 70, 2006.

[4] BELIZ, F. S. Construção de um jogo didático digital ligado à divulgação científica da astronomia. 2016. 112f. Dissertação (Mestrado Profissional em Astronomia) - Universidade Estadual de Feira de Santana, Feira de Santana, 2016.

[5] BORGES, T. O. Aprendizagem em astronomia: o desenvolvimento de uma sequência didática a partir de reflexões sobre a organização de cenas presentes no ambiente do planetário móvel da Universidade Estadual de Mato Grosso do Sul. 2017. 81f. Dissertação (Mestrado Profissional em Educação Científica e matemática) - Universidade Estadual de 
Mato Grosso do Sul, Dourados, 2017.

[6] BRETONES, P. S.; COMPIANI, M. A observação do céu como ponto de partida e eixo central em um curso de formação continuada de professores. Ensaio Pesquisa em Educação em Ciências, v. 12, n. 2, p. 173-188, 2010.

[7] BUENO, M. A. et al. Astronomia Cultural: um levantamento bibliográfico dos saberes sobre o céu de culturas indígenas. Revista Areté| Revista Amazônica de Ensino de Ciências, v. 11, n. 24, p. 27-40, 2019.

[8] BUFFON, A. D.; NEVES, M. C. D.; PEREIRA, R. F. Formação de Professores na Educação em Astronomia: uma análise do Banco de Dados de Teses e Dissertações do DME/UFSCar. Ensino \& Pesquisa, 2019.

[9] BUSSI, B.; BRETONES, P. S. Educação em Astronomia nos Trabalhos dos ENPECs de 1997 a 2011. Encontro Nacional de Pesquisa em Educação em Ciências, v. 9, 2013.

[10] FALCÃO, A. Museu como lugar de memória. In: Museu e escola: educação formal e não formal. Secretaria de Educação a Distância: Ministério da Educação. Ano XIX - n. 3 - p 10-21, 2009.

[11] FERREIRA, N.S.A. As pesquisas denominadas "Estado da Arte". Educação \& Sociedade, Campinas, v. 23, n. 79, 257-272, 2002.

[12] GOHN, M. G. Educação não-formal, participação da sociedade civil e estruturas colegiadas nas escolas. Ensaio: Avaliação e políticas públicas em Educação, 14(50), 7-38. 2006. Retrieved 16 January, 2020. www.scielo.br/pdf/ensaio/v14n50/30405.pdf.

[13] LANGHI, R. Educação em Astronomia: da revisão bibliográfica sobre concepções alternativas à necessidade de uma ação nacional. Caderno Brasileiro de Ensino de Física, Florianópolis, v. 28, n.2, p. 373-399, 2011.

[14] LANGHI, R.; NARDI, R. Ensino da astronomia no Brasil: educação formal, informal, não formal e divulgação científica. Revista Brasileira de Ensino de Física, Campinas, v. 31, n.4, p. 4402-4412, 2009.

[15] MARQUES, J. B. V. Educação Não-Formal e Divulgação de Astronomia no Brasil: Atores e Dinâmica da área na Perspectiva da Complexidade. 2017. 309f. Tese (Doutorado em Educação) - Universidade Federal de São Carlos, São Carlos, 2017.

[16] MARRANGHELlO, G. F. et al. Planetário da UNIPAMPA e a divulgação da ciência na região da campanha Sulriograndense. Revista Pesquisa e Debate em Educação, 8(2), 423 444, 2018.

[17] MEGID NETO, J. Educação ambiental como campo de conhecimento: a contribuição das pesquisas acadêmicas para sua consolidação no Brasil. Pesquisa em Educação Ambiental, Rio Claro, v. 4, n. 2, p. 95-110, 2009.

[18] ORTIZ, M. S. Valorização dos Saberes Astronômicos de uma Aldeia Indígena Terena no Estado de São Paulo. 2014. 101f. Dissertação (Mestrado em Educação para a Ciência) Faculdade de Ciências, Universidade Estadual Paulista, Bauru, 2014.

[19] ROSA, R. G. Do Big Bang ao cerrado atual: interdisciplinaridade no ensino de Ciências integrando espaços não formais. 2015. 79f. Dissertação (Mestrado em Educação em Ciências e Matemática) - Universidade Federal de Goiás, Goiânia, 2015.

[20] SANTOS, A. J. J.; VOELZKE, M. R.; ARAÚJO, M. S. T. O projeto Eratóstenes a reprodução de um experimento histórico como recurso para a inserção de conceitos da Astronomia no ensino médio. 2012.

[21] SANTOS, H. L. et al. O uso das tecnologias digitais para o ensino de Astronomia: uma revisão sistemática de literatura. Research, Society and Development, v. 8, n. 4, p. 37, 2019.

[22] SPINA, F. A. Linguagem Científica e Aprendizagem Significativa em Abordagem de Astronomia no Ensino Fundamental. 2017. 112f. Dissertação (Mestrado Profissional em 
Formação Científica, Educacional e Tecnológica) - Universidade Tecnológica Federal do Paraná, Curitiba, 2017.

[23] SILVA, A.H. et al. Análise de conteúdo: fazemos o que dizemos? Um levantamento de estudos que dizem adotar a técnica. Conhecimento Interativo, v. 11, n. 1, p. 168-184, 2017.

[24] YANO, V. T. B. Formação inicial e subjetividade docente no Centro de Ciências e Planetário do Pará. 2017. 117f. Dissertação (Mestrado em Educação em Ciências e Matemáticas) - Instituto de Educação Matemática e Científica, Universidade Federal do Pará, Belém, 2017.

[25] Resende, K. A. A. (2017). Interação entre o planetário e a escola: justificativas, dificuldades e propostas. (Dissertação de mestrado em Ensino). Universidade de São Paulo, São Paulo, SP. 